\title{
Uptake of tri-iodothyronine and thyroxine in myoblasts and myotubes of the embryonic heart cell line H9c2(2-1)
}

\author{
H H A G M van der Putten, B J L J Joosten, P H M Klaren \\ and $\mathbf{M}$ E Everts
}

Department of Veterinary Anatomy and Physiology, Utrecht University, PO Box 80.157, 3508 TD Utrecht, The Netherlands

(Requests for offprints should be addressed to M E Everts; Email: M.Everts@vet.uu.nl)

\begin{abstract}
Uptake of tri-iodothyronine $\left(\mathrm{T}_{3}\right)$ was compared with that of thyroxine $\left(\mathrm{T}_{4}\right)$ in the embryonic heart cell line H9c2 (2-1). These cells propagate as myoblasts and form differentiated myotubes upon reduction of the serum concentration, as indicated by a 31-fold increase in creatine kinase activity. Protein and DNA content per well were around 2-fold higher in myotubes than in myoblasts. When expressed per well, $\mathrm{T}_{3}$ and $\mathrm{T}_{4}$ uptake were, compared with myoblasts, 1.9- to 2-fold and 3.1- to 4-fold higher in myotubes respectively. On the other hand, the characteristics of $T_{3}$ and $T_{4}$ uptake were similar in myoblasts and myotubes. At any time-point, $\mathrm{T}_{4}$ uptake was 2 -fold higher than that of $\mathrm{T}_{3}$, and both uptakes were energy but not $\mathrm{Na}^{+}$ dependent. $T_{3}$ and $T_{4}$ uptake exhibited mutual inhibition

in myoblasts and myotubes: $10 \mu \mathrm{M}$ unlabeled $\mathrm{T}_{3}$ reduced $\mathrm{T}_{4}$ uptake by $51-60 \%(P<0 \cdot 001)$, while $10 \mu \mathrm{M} \mathrm{T}_{4}$ inhibited $\mathrm{T}_{3}$ uptake by $48-51 \%(P<0 \cdot 001)$. Furthermore, $\mathrm{T}_{3}$ and $\mathrm{T}_{4}$ uptake in myoblasts was dose-dependently inhibited by tryptophan (maximum inhibition around 70\%; $P<0 \cdot 001$ ). Exposure of the cells to $\mathrm{T}_{3}$ or $\mathrm{T}_{4}$ during differentiation significantly increased the fusion index (35 and $40 \% ; P<0 \cdot 01)$. Finally, both myoblasts and myotubes showed a small deiodinase type I activity, while deiodinase type II activity was undetectable. In conclusion, $\mathrm{T}_{3}$ and $\mathrm{T}_{4}$ share a common energy-dependent transport system in H9c2(2-1) cells, that may be important for the availability of thyroid hormone during differentiation.

Journal of Endocrinology (2002) 175, 587-596
\end{abstract}

\section{Introduction}

Thyroid hormones, thyroxine $\left(\mathrm{T}_{4}\right)$ and tri-iodothyronine $\left(\mathrm{T}_{3}\right)$, play a crucial role in normal growth and development of all organs including the heart. Early in the prenatal period, the fetus is supplied with maternal $\mathrm{T}_{4}$ through transport across the placenta (Obrégon et al. 1998). The fetal thyroid starts to produce thyroid hormones after 18-22 weeks of gestation in humans (Burrow et al. 1994) and at embryonic day 18 in rats (Obrégon et al. 1998). In both humans and rodents, the start of fetal thyroid activity is associated with a rise in cardiac contractility (Cluzeaut \& Maurer-Schultze 1986, Mayhew et al. 1997). Canavan et al. (1994) showed that hypothyroidism significantly delayed this development of the heart, while hyperthyroidism led to the opposite result.

The mechanisms by which $\mathrm{T}_{3}$ exerts its effects on the heart include binding of $\mathrm{T}_{3}$ to specific nuclear receptors (Lazar 1993, Muñoz \& Bernal 1997) as well as nongenomic cellular actions via the plasma membrane (Huang et al. 1999, Davis et al. 2002). The action of $\mathrm{T}_{4}$ on the heart is less well characterized. It has been shown that $\mathrm{T}_{4}$ stimulates differentiation of cardiomyocytes (Brik \& Shainberg 1990) and skeletal muscle cells
(Nakashima et al. 1998a,b), although the mode of action is not clear. The affinity of $\mathrm{T}_{4}$ for nuclear receptors is only one-tenth that of $T_{3}$ (Muñoz \& Bernal 1997), thereby making a nuclear pathway less likely. In some tissues, most of the $T_{3}$ associated with the nuclei is derived from the intracellular deiodination of $\mathrm{T}_{4}$, catalyzed by deiodinase type II (DII) (Visser 1996). Whether DII is present in human or rodent heart is still a matter of debate (Nauman et al. 1994, Croteau et al. 1996, Sabatino et al. 2000).

Rosic et al. (2001) examined the kinetics of $T_{3}$ and $T_{4}$ uptake in intact hearts and reported a saturable mechanism for the uptake of both $\mathrm{T}_{3}$ and $\mathrm{T}_{4}$. In our laboratory, uptake of $T_{3}$ and $T_{4}$ was investigated in cultures of neonatal rat cardiomyocytes (Everts et al. 1996b, van der Putten et al. 2001, Verhoeven et al. 2001, 2002). Under conditions where the free $T_{3}$ and $T_{4}$ concentrations were in the picomolar range, evidence was provided for a specific energy- and temperature-dependent mechanism for the uptake of $T_{3}$, while the results for $T_{4}$ were less equivocal. However, in two of these studies, it was found that unlabeled $\mathrm{T}_{4}$ reduced the uptake of $\mathrm{T}_{3}$, indicating that $\mathrm{T}_{4}$ might enter the cardiomyocytes through a mechanism comparable with that of $\mathrm{T}_{3}$ (van der Putten et al. 2001, 
Verhoeven et al. 2002). This idea is further explored in the present study.

While primary cultures of neonatal cardiomyocytes consist of a heterogeneous population of non-dividing and fully differentiated cells (Pinson 1990), the myogenic cell line H9c2(2-1) is a homogenous population of cardiac cells derived from embryonic rat heart tissue (Kimes \& Brandt 1976). A major advantage of this cell line is its ability to differentiate from mononucleated myoblasts into myotubes upon reduction of the serum concentration (Hescheler et al. 1991). Moreover, during the differentiation process the cells retain several elements of the electrical and hormonal signaling pathway of cardiac cells (Kimes \& Brandt 1976) and have therefore become an accepted in vitro model to study the effects of ischemia and diabetes on the heart (Eckel 1996, Brostrom et al. 2000, Wayman et al. 2001). In addition, Gerrelli et al. (1994) showed that exposure of the H9c2(2-1) cells to thyroid hormone resulted in an increased expression of the cardiac spliceosome protein $\mathrm{SmN}$, indicating that the cells are $\mathrm{T}_{3}$ responsive.

In the present study, $T_{3}$ and $T_{4}$ uptake was characterized and compared in the H9c2(2-1) cells. To understand the role of thyroid hormone uptake mechanisms during cardiac differentiation, $\mathrm{T}_{3}$ and $\mathrm{T}_{4}$ uptake was compared in undifferentiated myoblasts and differentiated myotubes. In addition, we examined the effects of $T_{3}$ and $T_{4}$ on the fusion index as an indicator of the degree of differentiation.

\section{Materials and Methods}

\section{Materials}

Cell culture reagents were purchased from Life Technologies (Breda, The Netherlands). Bovine serum albumin (BSA; fraction V) was obtained from Roche (Mannheim, Germany). L-tri-iodothyronine $\left(\mathrm{T}_{3}\right)$, L-thyroxine $\left(\mathrm{T}_{4}\right)$, L-tryptophan (Trp) and oligomycin were purchased from Sigma (St Louis, MO, USA), L-isomers of $\left[{ }^{125} \mathrm{I}^{1} \mathrm{~T}_{3}(24 \cdot 4\right.$ $\mathrm{TBq} / \mathrm{mmol}),\left[{ }^{125} \mathrm{I}\right] \mathrm{T}_{4}(4 \cdot 3 \mathrm{TBq} / \mathrm{mmol})$ and $\left[{ }^{125} \mathrm{I}\right]$ reverse $\mathrm{T}_{3}\left(\mathrm{rT}_{3} ; 28.0 \mathrm{TBq} / \mathrm{mmol}\right)$ were from NEN (Boston, MA, USA). Prior to use $\left[{ }^{125} \mathrm{I}\right] \mathrm{T}_{4}$ and $\left[{ }^{125} \mathrm{I}\right] \mathrm{rT}_{3}$ were purified by Sephadex LH-20 column chromatography (Mol \& Visser 1985).

\section{Cell culture}

The rat embryonic cardiac cell line H9c2(2-1) was obtained from the European Collection of Cell Cultures (Salisbury, Wilts, UK). Cells were seeded into 24-well culture dishes at a density of $0.5 \times 10^{5}$ cells/well and propagated as myoblasts at $37^{\circ} \mathrm{C}$ in a $5 \% \mathrm{CO}_{2}$ atmosphere in Dulbecco's modified Eagle's medium (DMEM) supplemented with $10 \%(\mathrm{v} / \mathrm{v})$ fetal calf serum (FCS) and $100 \mathrm{U} / \mathrm{ml}$ penicillin-streptomycin. At day 2 after seeding, half of the culture was used for uptake experiments, while the other half was kept for 7 days in DMEM containing
$1 \%(\mathrm{v} / \mathrm{v})$ FCS and $100 \mathrm{U} / \mathrm{ml}$ penicillin-streptomycin to obtain fused myotubes. At day 2, the cultures were $80 \%$ confluent, presumably corresponding to around $2 \times 10^{5}$ cells/well. Medium was changed every $48 \mathrm{~h}$. For the deiodinase assays, cells were seeded in $75 \mathrm{~cm}^{2}$ culture flasks at a density of $2 \times 10^{6}$ cells/flask and further processed under the same conditions as described above for cells seeded in 24-well culture dishes.

\section{Cellular uptake studies}

Uptake experiments were performed at days 2 and 9 after seeding, at which time the culture consisted of myoblasts and myotubes respectively. After removal of the culture medium, cells were preincubated for $30 \mathrm{~min}$ at $37^{\circ} \mathrm{C}$ in $0.5 \mathrm{ml}$ Krebs-Ringer medium $(139 \mathrm{mM} \mathrm{NaCl}, 4.2 \mathrm{mM}$ $\mathrm{KCl}, 1.5 \mathrm{mM} \mathrm{CaCl}_{2}, 1.4 \mathrm{mM} \mathrm{KH}_{2} \mathrm{PO}_{4}, 1.4 \mathrm{mM} \mathrm{MgSO}_{4}$, $5.0 \mathrm{mM}$ glucose; prepared in $25 \mathrm{mM}$ Tris at $\mathrm{pH} 7.4$ ) supplemented with $0 \cdot 1 \%$ BSA for determination of $\mathrm{T}_{4}$ uptake or $0.5 \%$ BSA for $\mathrm{T}_{3}$ uptake. Incubation was initiated by quickly replacing the preincubation medium with $0.5 \mathrm{ml}$ Krebs-Ringer buffer containing the additions described below and either $4 \times 10^{5}$ c.p.m. $/ \mathrm{ml}^{125}{ }^{125} \mathrm{~T}_{4}$, $10 \mathrm{nM} \mathrm{T}_{4}$ and $0 \cdot 1 \% \mathrm{BSA}$, or $4 \times 10^{5}$ c.p.m. $/ \mathrm{ml}\left[{ }^{125} \mathrm{I}^{5} \mathrm{~T}_{3}\right.$, $10 \mathrm{nM} \mathrm{T}_{3}$ and $0.5 \% \mathrm{BSA}$. Incubations were performed at $37^{\circ} \mathrm{C}$, and the culture dishes were mildly agitated. Uptake was terminated by quick aspiration of the incubation medium, and cells were washed three times with $1 \mathrm{ml}$ ice-cold saline. Cells were dissolved in $1 \mathrm{ml} 0 \cdot 1 \mathrm{M} \mathrm{NaOH}$ and analyzed for ${ }^{125} \mathrm{I}$ activity in a $\gamma$-counter (Packard Cobra II; Packard Instruments Co., Meriden, CT, USA). The time-course of $T_{3}$ and $T_{4}$ uptake was assayed in the presence or absence of sodium. Sodium-free conditions were attained by replacing sodium with choline on a mol-for-mol basis in the preincubation and incubation media. When the effects of unlabeled $\mathrm{T}_{3}$ and $\mathrm{T}_{4}$ on 30 -min uptake were examined, $10 \mu \mathrm{M}$ of the unlabeled compound was added to the incubation medium. In all other experiments, the compounds were present during preincubation and incubation $(10 \mu \mathrm{M}$ oligomycin and 0.5 or $2 \mathrm{mM}$ Trp).

The amount of $\left[{ }^{125} \mathrm{I}\right] \mathrm{T}_{3}$ or $\left[{ }^{125} \mathrm{I}\right] \mathrm{T}_{4}$ associated with the cells, representing total cellular uptake, was expressed as $\mathrm{fM} / \mathrm{pM}$ free hormone (see Free hormone fraction section). Results were corrected for the amount of ${ }^{125} \mathrm{I}$ activity associated with the walls of the culture wells. In experiments where uptake was measured in the presence of $10 \mu \mathrm{M}$ unlabeled hormone, the saturable part of $\left[{ }^{125} \mathrm{I}\right] \mathrm{T}_{3}$ uptake varied between 56 and $73 \%$ in myotubes and myoblasts respectively. For $\left[{ }^{125} \mathrm{I}^{\mathrm{T}} \mathrm{T}_{4}\right.$ uptake, these values varied between 33 and 39\% in myoblasts and myotubes respectively.

\section{Light microscopy and determination of fusion index}

At days 2, 7 and 9 after seeding, cultures were fixed subsequently with $70 \%(\mathrm{v} / \mathrm{v})$ and $96 \%(\mathrm{v} / \mathrm{v})$ ethanol and 
stained with 100\% hematoxylin. Nuclei were counted using an inverted microscope (Nikon TMS-F, Bunnik, The Netherlands). Digital images were acquired using a Nikon Coolpix 990 camera. The fusion index was determined in ten microscopic fields and calculated by dividing the number of nuclei in the myotubes by the total number of nuclei. Myotubes were defined as cells containing three or more nuclei.

\section{Creatine kinase (CK) activity measurements}

After removal of the culture medium, the cells were lysed in $500 \mu \mathrm{l} 0 \cdot 5 \%(\mathrm{v} / \mathrm{v})$ Triton X-100 in phosphate-buffered saline and mildly agitated for $10 \mathrm{~min}$ at room temperature. The cellular debris was scraped from the well using a rubber spatula and the lysate was collected in a tube. CK activity was determined with an NAC-activated CK-kit (Sigma) according to the manufacturer's protocol.

\section{Protein and DNA measurements}

Cellular protein was measured according to the method of Lowry et al. (1951). DNA was quantified using a Hoechst fluorescence staining method (Downs \& Wilfinger 1983).

\section{Free hormone fraction}

Calculations of free $T_{3}$ and $T_{4}$ concentrations were based on the determination of the free hormone fraction by equilibrium dialysis (Sterling \& Brenner 1966). In KrebsRinger medium containing $4 \times 10^{5}$ c.p.m. $/ \mathrm{ml}\left[{ }^{125} \mathrm{I}\right] \mathrm{T}_{3}$, $10 \mathrm{nM} \mathrm{T} \mathrm{T}_{3}$ and $0.5 \%$ BSA the free $\mathrm{T}_{3}$ fraction was $3 \cdot 9 \pm 0 \cdot 3 \%(n=5)$. Addition of $10 \mu \mathrm{M} \mathrm{T} \mathrm{T}_{3}, 10 \mu \mathrm{M} \mathrm{T}$, $10 \mu \mathrm{M}$ oligomycin or a combination of oligomycin and $\mathrm{T}_{3}$ (both at $10 \mu \mathrm{M}$ ) changed the free $\mathrm{T}_{3}$ fraction to $4 \cdot 6 \pm 0 \cdot 1 \%(n=3), 4 \cdot 7 \pm 0 \cdot 0 \%(n=4), 3 \cdot 8 \pm 0 \cdot 1 \% \quad(n=4)$ and $4.9 \pm 0 \cdot 1 \%(n=4)$ respectively. The free $\mathrm{T}_{4}$ fraction in Krebs-Ringer medium with $4 \times 10^{5}$ c.p.m. $/ \mathrm{ml}^{125} \mathrm{I}^{12} \mathrm{~T}_{4}$, $10 \mathrm{nM} \mathrm{T}_{4}$ and $0 \cdot 1 \%$ BSA was $3 \cdot 3 \pm 0 \cdot 5 \%(n=3)$ and changed in the presence of $10 \mu \mathrm{M} \mathrm{T}_{4}, 10 \mu \mathrm{M} \mathrm{T}, 10 \mu \mathrm{M}$ oligomycin or a combination of oligomycin and $\mathrm{T}_{4}$ (both at $10 \mu \mathrm{M})$ to $5 \cdot 1 \pm 0 \cdot 4 \% \quad(n=3), \quad 4 \cdot 1 \pm 0 \cdot 3 \% \quad(n=4)$, $3 \cdot 5 \pm 0 \cdot 1 \%(n=4)$ and $5 \cdot 4 \pm 0 \cdot 5 \%(n=4)$ respectively. The presence of $2 \mathrm{mM}$ Trp did not alter the free fraction of $\mathrm{T}_{3}$ or $\mathrm{T}_{4}$.

Furthermore, the free $\mathrm{T}_{3}$ and $\mathrm{T}_{4}$ fractions, analyzed in DMEM supplemented with $1 \%$ FCS, were $4 \cdot 4 \pm 0 \cdot 4 \%$ $(n=3)$ and $3 \cdot 0 \pm 0 \cdot 1 \%(n=3)$ respectively.

\section{Deiodinase assays}

DI and DII activities were determined in myoblasts and myotubes and compared with those of adult rat liver homogenate. DI and DII assays were performed as previously described (Sabatino et al. 2000) with the following modifications. After removal of the culture medium, the cells were scraped from the culture flask using a rubber spatula and collected in $1 \mathrm{ml}$ buffer consisting of $250 \mathrm{mM}$ sucrose, $10 \mathrm{mM}$ Hepes, $10 \mathrm{mM}$ Tris, $\mathrm{pH} 8$ and $1 \mathrm{mM}$ dithiothreitol (DTT). Subsequently, the cells were homogenized using a Potter-Elvejhem device (Heidolph RZR 2020, Schwabach, Germany) equipped with a Teflon pestle. For measurement of DI activity, $100 \mu \mathrm{l}$ aliquots of the homogenates $(10 \mu \mathrm{g}$ protein in a total assay volume of $200 \mu \mathrm{l})$ were incubated in triplicate for $15 \mathrm{~min}$ at $37^{\circ} \mathrm{C}$ in $100 \mu \mathrm{l}$ incubation medium $(100 \mathrm{mM}$ phosphate buffer, $2 \mathrm{mM}$ EDTA, $10 \mathrm{mM}$ DTT) containing $1 \times 10^{6}$ c.p.m. $\left./ \mathrm{ml}^{[125} \mathrm{I}\right] \mathrm{rT}_{3}$ and $1 \mu \mathrm{M} \mathrm{rT}$ in the presence or absence of $100 \mu \mathrm{M}$ propylthiouracil (PTU). The reaction was quenched by adding $100 \mu \mathrm{l} 5 \%(\mathrm{w} / \mathrm{v})$ ice-cold BSA followed by $500 \mu \mathrm{l} 10 \%(\mathrm{v} / \mathrm{v})$ trichloroacetic acid for deproteinization. Samples were centrifuged for $15 \mathrm{~min}$ at $4{ }^{\circ} \mathrm{C}$ and $1500 \mathrm{~g}$ (Heraus labofuge 400R, Hanau, Germany) and $500 \mu \mathrm{l}$ of the supernatant was acidified with $500 \mu \mathrm{l} 1 \mathrm{M} \mathrm{HCl}$. Liberated iodide was analyzed by Sephadex LH-20 column chromatography. The first three eluates were collected with three times $1 \mathrm{ml} 0 \cdot 1 \mathrm{M} \mathrm{HCl}$ and analyzed for ${ }^{125} \mathrm{I}$ activity in a $\gamma$-counter (Packard Cobra II). Specific DI activity was defined as the PTUinhibitable part of iodide production. For measurement of DII activity, $100 \mu \mathrm{l}$ aliquots of homogenates $(10 \mu \mathrm{g}$ protein in a total assay volume of $200 \mu \mathrm{l}$ ) were incubated in triplicate under the same conditions as for the DI assay,

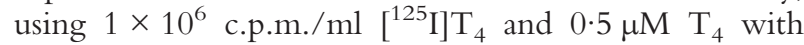
$20 \mathrm{mM}$ DTT. PTU was omitted from the incubation medium.

\section{Statistics}

Data are presented as means \pm S.E.M., unless stated otherwise. Statistical significance was evaluated by repeated measures ANOVA or Student's $t$-test, where appropriate. Statistical significance was accepted at $P<0 \cdot 05$.

\section{Results}

\section{Characterization of the cell culture}

In initial experiments, we followed the differentiation of the H9c2(2-1) myoblasts into myotubes. DNA and protein content both increased during the first days of culture (Fig. 1A and C). At day 9, DNA content of the cells had reached a constant level, characteristic of non-dividing myotubes. Furthermore, DNA and protein contents of the myotubes (day 9) were around 1.8- and 1.9-fold higher respectively, compared with myoblasts (day 2) $(P<0 \cdot 001)$.

Myotubes are characterized by the expression of CK and the activity of this enzyme is markedly increased during differentiation (Kimes \& Brandt 1976). CK activity per well measured at days 2, 7 and 9 is shown in Fig. 1B. CK activity increased 9-fold from day 2 to day 7 


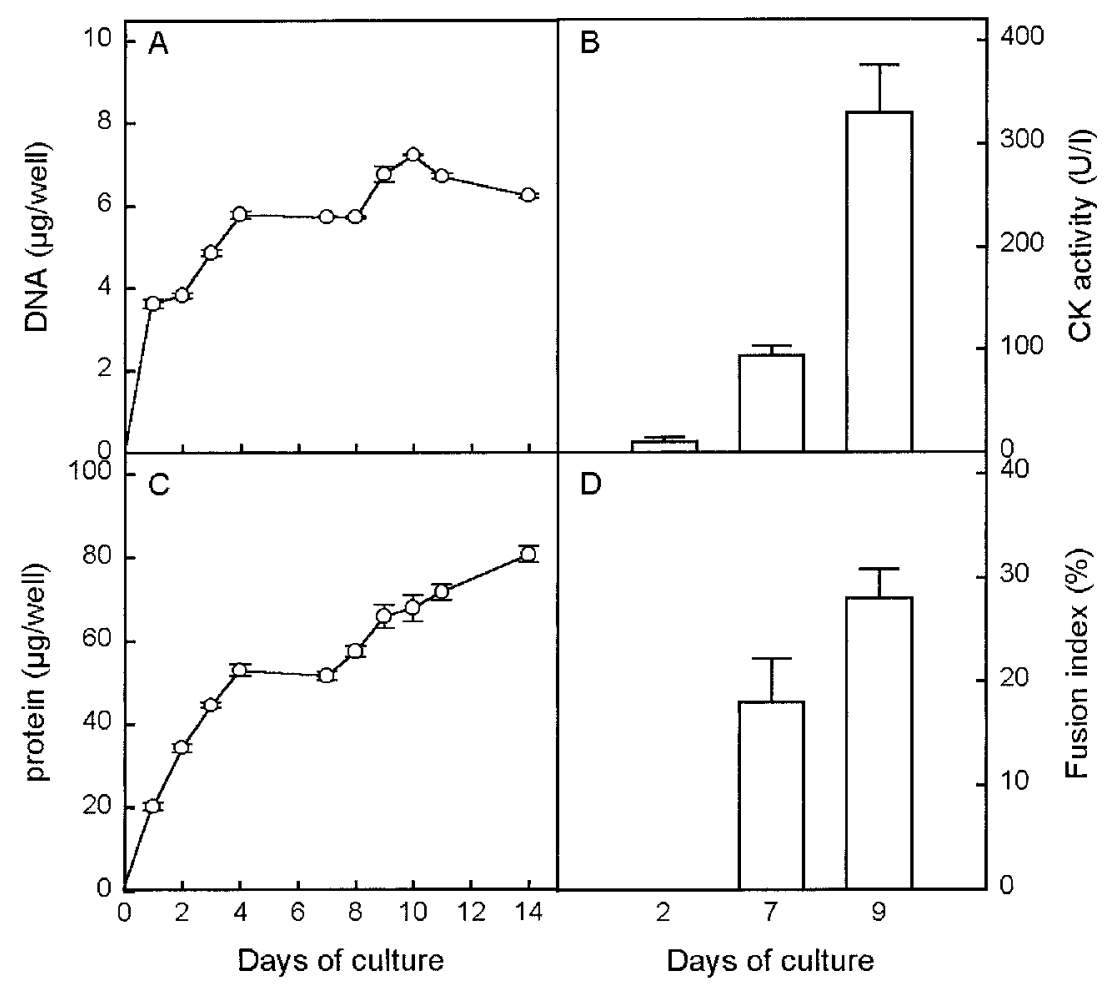

Figure 1 Characterization of $\mathrm{H} 9 \mathrm{c} 2(2-1)$ cell line during differentiation. Myoblasts were seeded at a density of $5 \times 10^{5}$ cells/well and cultured for 2 days in DMEM supplemented with $10 \%$ FCS. At day 2 the FCS in the medium was reduced to $1 \%$ to induce differentiation of myoblasts into myotubes. (A) DNA $(n=3)$ and (C) protein $(n=3)$ content of the cells was determined throughout the culture period. (B) The CK activity per well $(n=10)$ and (D) the degree of fusion in percent (means \pm S.D., $n=2)$ were determined at days 2,7 and 9 of culture.

$(P<0 \cdot 001)$ and $3 \cdot 5$-fold from day 7 to day 9 (not significant). The total rise from day 2 to day 9 was 31 -fold $(P<0 \cdot 001)$.

Myoblast differentiation into myotubes can be quantified by measuring the fusion index, which is the percentage of nuclei incorporated into myotubes relative to the total number. Figure 1D shows that the fusion index increased from $0 \%$ to $18 \pm 4 \%$ at day 7 and further increased to $28 \pm 3 \%$ at day 9 , the only statistical significant increase being from day 2 to day $7(P<0 \cdot 01)$.

In Fig. 2, a light microscopic view of myoblasts (Fig. 2A) and myotubes (Fig. 2B) is shown. Myoblasts are large, flat, spindle-shaped, mononucleated cells which do not organize themselves into orderly arrays. In contrast, myotubes are fused multi-nucleated cells organized in linear parallel arrays.

Time-course of $T_{3}$ and $T_{4}$ uptake

Figure $3 \mathrm{~A}$ shows the time-course of $\left[{ }^{125} \mathrm{I}\right] \mathrm{T}_{3}$ uptake in myoblasts and myotubes. In myoblasts, uptake showed a steep increase up to $1.5 \mathrm{~h}$, and then slowly leveled off. In myotubes, uptake also leveled off after $1.5 \mathrm{~h}$ of incubation. When expressed per well, $\left[{ }^{125} \mathrm{I}\right] \mathrm{T}_{3}$ uptake in myotubes was around 1.9- to 2.5-fold higher than in myoblasts. However, when the data were expressed relative to the protein content, $\left[{ }^{125} \mathrm{I}\right] \mathrm{T}_{3}$ uptake in myotubes was around 1 - to $1 \cdot 3$-fold higher compared with myoblasts. $\left[{ }^{125} \mathrm{I}\right] \mathrm{T}_{3}$ uptake in myoblasts and myotubes was not inhibited by replacement of $\mathrm{Na}^{+}$by choline in the medium, indicating that $\left[{ }^{125} \mathrm{I}^{\mathrm{T}} \mathrm{T}_{3}\right.$ uptake is $\mathrm{Na}^{+}$independent (Fig. 3A).

$\mathrm{T}_{4}$ uptake in myoblasts and myotubes as a function of incubation time leveled off after $1 \mathrm{~h}$ of incubation (Fig. 3B). $\left[{ }^{125} \mathrm{I}\right] \mathrm{T}_{4}$ uptake per well was $3 \cdot 1$ - to 4 -fold higher in myotubes than in myoblasts. When the uptake was expressed relative to the protein content of the wells, $\left[{ }^{125} \mathrm{I}\right] \mathrm{T}_{4}$ uptake in myotubes was around $1 \cdot 6$ - to $2 \cdot 2$-fold higher than in myoblasts $(P<0 \cdot 05)$. This is somewhat higher than the difference in $\left[{ }^{125} \mathrm{I}_{3} \mathrm{~T}_{3}\right.$ uptake between myotubes and myoblasts (see above). Furthermore, $\left[{ }^{125} \mathrm{I}\right] \mathrm{T}_{4}$ uptake in myoblasts and myotubes was $\mathrm{Na}^{+}$ independent (Fig. 3B). 


\section{A}

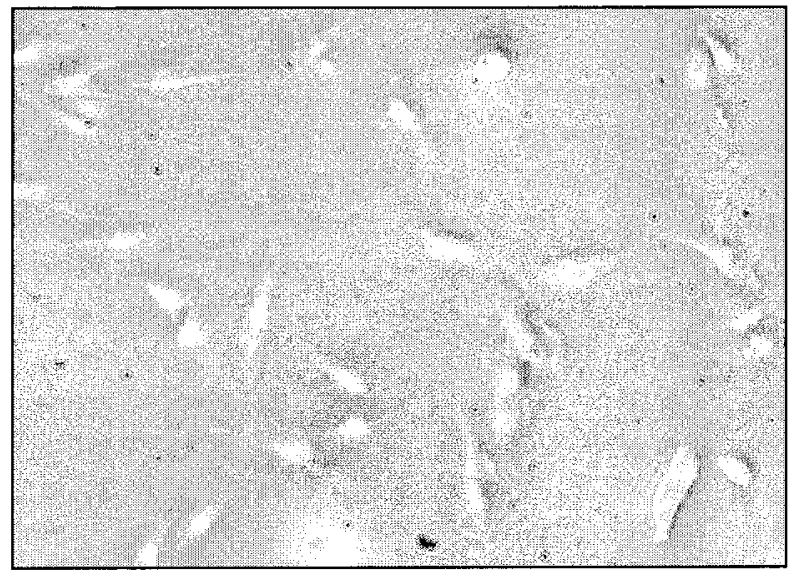

B

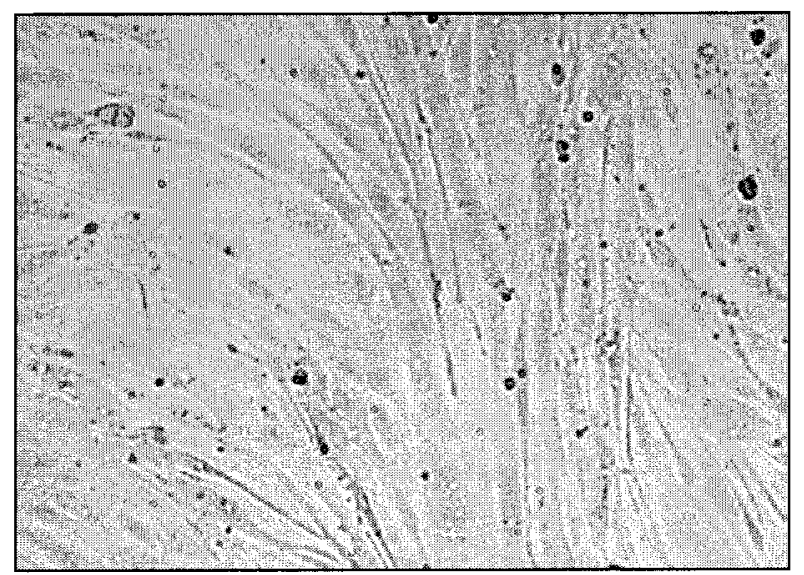

Figure 2 Phase-contrast pictures $(10 \times)$ of $\mathrm{H} 9 \mathrm{c} 2(2-1)(\mathrm{A})$ myoblasts and (B) myotubes. Myoblasts were seeded at a density of $5 \times 10^{5}$ cells/well and cultured for 2 days in DMEM supplemented with $10 \%$ FCS. At day 2 the FCS in the medium was reduced to $1 \%$ to induce differentiation of myoblasts into myotubes. The digital image of the myoblasts was taken at day 2, and that of the myotubes at day 9.

\section{Comparison of $\left[{ }^{125} I\right] \mathrm{T}_{3}$ and $\left[{ }^{125} I\right] \mathrm{T}_{4}$ uptake}

Figure 4 shows $30-$ min uptake of $\left[{ }^{125} \mathrm{I}\right] \mathrm{T}_{3}$ (left side) and ${ }^{125} \mathrm{I}^{12} \mathrm{~T}_{4}$ (right side) in myoblasts. The control values for uptake of $\left[{ }^{125} \mathrm{I}\right] \mathrm{T}_{3}$ and $\left[{ }^{125} \mathrm{I}\right] \mathrm{T}_{4}$ were $0 \cdot 040 \pm 0 \cdot 001 \mathrm{fM} /$ $\mathrm{pM}$ free $\mathrm{T}_{3}$ and $0.072 \pm 0.003 \mathrm{fM} / \mathrm{pM}$ free $\mathrm{T}_{4}$ respectively, a $1 \cdot 8$-fold difference $(P<0 \cdot 001)$. $\left[{ }^{125} \mathrm{I}\right] \mathrm{T}_{3}$ uptake was significantly inhibited by $10 \mu \mathrm{M}$ unlabeled $\mathrm{T}_{3}(73 \%$; $P<0 \cdot 001)$ and $10 \mu \mathrm{M}$ unlabeled $\mathrm{T}_{4}(48 \% ; P<0 \cdot 001)$ (Fig. 4 , left side). Oligomycin, added at a concentration of $10 \mu \mathrm{M}$, significantly inhibited $\left[{ }^{125} \mathrm{I}^{2} \mathrm{~T}_{3}\right.$ uptake by $20 \%$ $(P<0 \cdot 01)$. Co-incubation with $10 \mu \mathrm{M}$ unlabeled $\mathrm{T}_{3}$ and $10 \mu \mathrm{M}$ oligomycin resulted in a $65 \%(P<0 \cdot 001)$ reduction of $\mathrm{T}_{3}$ uptake, comparable with the effect of unlabeled $\mathrm{T}_{3}$ alone. Similar experiments were performed with $\left[{ }^{125} \mathrm{I}\right] \mathrm{T}_{4}$ uptake in myoblasts (Fig. 4, right side). $\left[{ }^{125} \mathrm{I}^{\mathrm{T}} \mathrm{T}_{4}\right.$ uptake was significantly reduced by $10 \mu \mathrm{M}$ unlabeled $\mathrm{T}_{4}(33 \%$; $P<0 \cdot 001)$ and $10 \mu \mathrm{M}$ unlabeled $\mathrm{T}_{3}(60 \% ; P<0 \cdot 001)$. $\left[{ }^{125} \mathrm{I}\right] \mathrm{T}_{4}$ uptake in myoblasts was not inhibited when $10 \mu \mathrm{M}$ oligomycin was added to the incubation medium. Co-incubation of $10 \mu \mathrm{M}$ unlabeled $\mathrm{T}_{4}$ and $10 \mu \mathrm{M}$ oligomycin resulted in an inhibition comparable with the effect of $\mathrm{T}_{4}$ alone $(35 \% ; P<0 \cdot 001)$.

Uptake of $\left[{ }^{125} \mathrm{I}\right] \mathrm{T}_{3}$ and $\left[{ }^{125} \mathrm{I}\right] \mathrm{T}_{4}$ was examined in parallel in myotubes (Fig. 5) and showed the following control values: $0.088 \pm 0.005 \mathrm{fM} / \mathrm{pM}$ free $\mathrm{T}_{3}$ and $0 \cdot 180 \pm 0 \cdot 008 \mathrm{fM} / \mathrm{pM}$ free $\mathrm{T}_{4}$ respectively, a 2 -fold difference $(P<0 \cdot 05)$. Unlabeled $\mathrm{T}_{3} \quad(10 \mu \mathrm{M})$ inhibited $\left[{ }^{125} \mathrm{I}_{\mathrm{T}}\right.$ and $\left[{ }^{125} \mathrm{I}\right] \mathrm{T}_{4}$ uptake by $56 \%(P<0 \cdot 001)$ and $51 \%$ $(P<0 \cdot 001)$ respectively. Unlabeled $\mathrm{T}_{4}$ inhibited $\left[{ }^{125} \mathrm{I}\right] \mathrm{T}_{3}$ and $\left[{ }^{125} \mathrm{I}_{\mathrm{T}} \mathrm{T}_{4}\right.$ uptake by $51 \% \quad(P<0 \cdot 001)$ and $39 \%$ $(P<0 \cdot 001)$ respectively. When myotubes were incubated with $10 \mu \mathrm{M}$ oligomycin, $\left[{ }^{125} \mathrm{I}\right] \mathrm{T}_{3}$ uptake was reduced by $31 \%(P<0.001)$ (Fig. 5, left side) and $\left[{ }^{125} \mathrm{I}\right] \mathrm{T}_{4}$ uptake was reduced by $26 \%(P<0 \cdot 01)$ (Fig. 5 , right side). The effect of co-incubation of oligomycin and unlabeled $\mathrm{T}_{3}$ on $\left[{ }^{125} \mathrm{I}\right] \mathrm{T}_{3}$ uptake in myotubes was comparable with the effect of unlabeled hormone alone $(56 \% ; P<0 \cdot 001)$. This was also found for $\left[{ }^{125} \mathrm{I}\right] \mathrm{T}_{4}$ uptake in the presence of oligomycin and unlabeled $\mathrm{T}_{4}(40 \% ; P<0 \cdot 001)$.

\section{Effect of Trp on $\left[{ }^{125} I\right] T_{3}$ uptake}

To test the possible involvement of amino acid transport system $\mathrm{T}$ in the uptake of $\left[{ }^{125} \mathrm{I}\right] \mathrm{T}_{3}$ and $\left[{ }^{125} \mathrm{I}\right] \mathrm{T}_{4}$, we preincubated and incubated $(30 \mathrm{~min})$ myoblasts and myotubes with 0.5 and $2 \mathrm{mM}$ Trp. $\left[{ }^{125} \mathrm{I}\right] \mathrm{T}_{3}$ and $\left[{ }^{125} \mathrm{I}\right] \mathrm{T}_{4}$ uptake were dose-dependently inhibited by Trp, with a maximal effect of $69 \%$ and $71 \%$ respectively $(P<0 \cdot 001)$ (Table 1).

In myotubes, $\left[{ }^{125} \mathrm{I}^{\mathrm{T}} \mathrm{T}_{3}\right.$ uptake decreased from $0.063 \pm 0.001 \mathrm{fM} / \mathrm{pM}$ free $\mathrm{T}_{3}$ to $0.032 \pm 0.001 \mathrm{fM} / \mathrm{pM}$ free $\mathrm{T}_{3}$ in the presence of $2 \mathrm{mM} \operatorname{Trp}(49 \%, P<0 \cdot 001)$.

\section{Effect of $T_{3}$ and $T_{4}$ on differentiation of $H 9 c 2(2-1)$ cells}

By comparing the fusion index of cultures exposed to $5 \mathrm{nM} \mathrm{T}_{3}$ or $50 \mathrm{nM} \mathrm{T} \mathrm{T}_{4}$ with that of control cultures, the effect of $\mathrm{T}_{3}$ or $\mathrm{T}_{4}$ treatment on differentiation could be examined. Under these conditions with $1 \%$ FCS in the medium, the free $T_{3}$ and $T_{4}$ concentrations were 0.2 and $1.5 \mathrm{nM}$ respectively. The fusion index was determined on days 2, 3, 7 and 9 (Fig. 6). In general, the fusion index increased from day 2 to day 9 , reflecting the morphological differentiation of the cells (see also Fig. 1D). Only at day 9 did exposure to $\mathrm{T}_{3}$ and $\mathrm{T}_{4}$ significantly stimulate fusion: $\mathrm{T}_{3}$ treatment by $35 \pm 2 \%(P<0 \cdot 01$ vs control at day 9$)$, and $\mathrm{T}_{4}$ by $40 \pm 2 \%(P<0 \cdot 001$ vs control at day 9$)$, as compared with $26 \pm 1 \%$ in the control cultures. In addition, the effect of $\mathrm{T}_{3}$ was not statistically different from that of $\mathrm{T}_{4}$. 

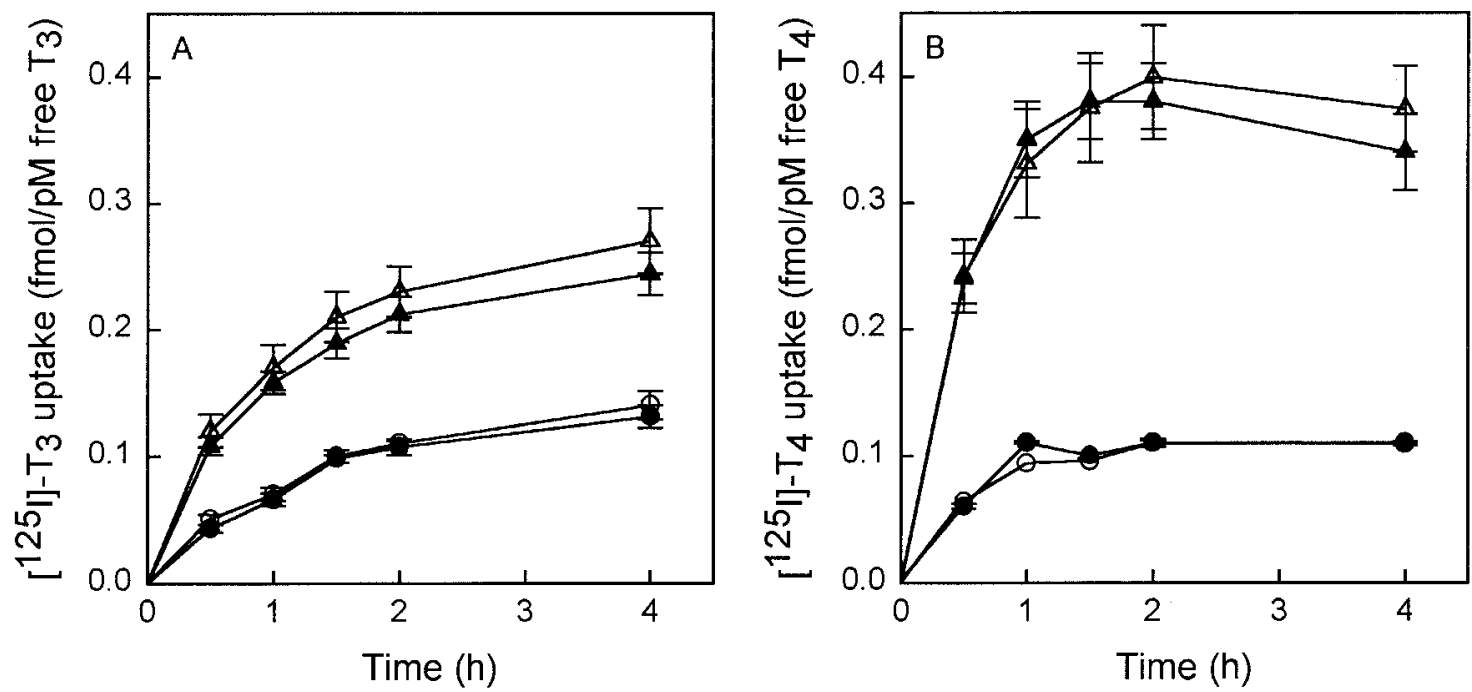

Figure 3 Time-course of $(A)\left[{ }^{125} I\right] \mathrm{T}_{3}$ uptake and $(\mathrm{B})\left[{ }^{125} \mathrm{I}\right] \mathrm{T}_{4}$ uptake in myoblasts (circles) and myotubes (triangles). $\mathrm{H} 9 \mathrm{C} 2(2-1)$ cells were cultured as described in the legend to Fig. 1. Uptake experiments were performed at day 2 with myoblasts and at day 9 with myotubes. The uptake of $\left[{ }^{125} \mathrm{I}\right] \mathrm{T}_{3}$ was measured in Krebs-Ringer medium with $\mathrm{Na}^{+}$(solid symbols) or in Krebs-Ringer in which $\mathrm{Na}^{+}$was replaced by choline (open symbols), both supplemented with $0.5 \%$ BSA. For uptake of $\left[{ }^{125} \mathrm{I}_{4}\right.$, the media were supplemented with $0 \cdot 1 \%$ BSA. Data show the means \pm S.E.M. of $7-13$ observations of five experiments for $\left[{ }^{125} \mathrm{I}\right] \mathrm{T}_{3}$ uptake and of 6 observations from two experiments for [ $\left.{ }^{125} \mathrm{I}\right] \mathrm{T}_{4}$ uptake.

This effect was not accompanied by an increase in DNA and protein content nor in CK activity (data not shown). The control values of these parameters resembled those depicted in Fig. 1.

\section{Deiodinase activity}

DI activity was $0.32 \pm 0.05 \mathrm{fmol} / \mu \mathrm{g}$ protein per min in myoblasts $(n=3)$ and $0.22 \pm 0.07 \mathrm{fmol} / \mu \mathrm{g}$ protein per min in myotubes $(n=3)$ respectively. The H9c2(2-1) cells did not exhibit DII activity (data not shown). In the same experiments, DI and DII activity in homogenates of adult rat liver amounted to around $30 \mathrm{fmol} / \mu \mathrm{g}$ protein per min and less than $1 \mathrm{fmol} / \mu \mathrm{g}$ protein per min respectively.

\section{Discussion}

In the present study we examined $\mathrm{T}_{3}$ and $\mathrm{T}_{4}$ uptake in the H9c2(2-1) cell line derived from embryonic rat heart. Uptake of $\mathrm{T}_{3}$ in these cells was inhibited by unlabeled $\mathrm{T}_{3}$, $\mathrm{T}_{4}$ and Trp. Incubation with oligomycin reduced $\mathrm{T}_{3}$ uptake, indicating the energy dependence of the process. $\mathrm{T}_{3}$ uptake was not $\mathrm{Na}^{+}$dependent. These observations provide evidence for a specific $\mathrm{T}_{3}$ uptake mechanism in H9c2(2-1) cells. $\mathrm{T}_{4}$ uptake at $30 \mathrm{~min}$ was around 2 -fold higher than that of $\mathrm{T}_{3}$, and the characteristics of uptake, e.g. energy dependence, $\mathrm{Na}^{+}$independence and ligand specificity were comparable with that of $\mathrm{T}_{3}$. These observations support the idea that $T_{4}$ and $T_{3}$ share a common uptake mechanism in the H9c2(2-1) cells. Moreover, both $\mathrm{T}_{3}$ and $\mathrm{T}_{4}$ stimulated differentiation at concentrations $(0 \cdot 2-1.5 \mathrm{nM})$ in the range of that used in the uptake studies (both around $0.3 \mathrm{nM}$ ).

We here present evidence that the H9c2(2-1) cells possess a specific mechanism for the uptake of $\mathrm{T}_{4}$. Whereas carrier-mediated uptake of $T_{3}$ has been demonstrated in various tissues (Kragie 1994, Hennemann et al. 2001), evidence for an active transport mechanism for $T_{4}$ is not as abundant. $\mathrm{T}_{4}$ uptake has been explored in hepatocytes (Krenning et al. 1981), anterior pituitary cells (Everts et al. 1994), neuroblastoma cells (Lakshmanan et al. 1990), fibroblasts (Docter et al. 1987, Benvenga \& Robbins 1990) and skeletal muscle (van Hardeveld \& Kassenaar 1978). $T_{4}$ uptake in these cell types is mediated by a saturable and energy-dependent mechanism. $\mathrm{T}_{4}$ uptake showed a steeper time-course compared with $T_{3}$. On the other hand, the characteristics of $\mathrm{T}_{3}$ and $\mathrm{T}_{4}$ uptakes were comparable in myotubes and myoblasts. First, $T_{3}$ and $T_{4}$ uptakes were inhibited roughly to the same extent by oligomycin (most clearly in myotubes) and, thus, $T_{3}$ and $T_{4}$ uptakes depend on the energy status of the cell. Secondly, $\mathrm{T}_{3}$ and $\mathrm{T}_{4}$ uptakes did not depend on the $\mathrm{Na}^{+}$gradient. Thirdly, the uptakes exhibited mutual inhibition, but the effect of unlabeled $\mathrm{T}_{3}$ on $\mathrm{T}_{4}$ uptake was somewhat larger than that of unlabeled $\mathrm{T}_{4}$, probably because of the higher free $T_{3}$ concentration in medium with $0 \cdot 1 \%$ BSA compared with that of $\mathrm{T}_{4}$. Together these findings are consistent with the idea that $\mathrm{T}_{3}$ and $\mathrm{T}_{4}$ share the same transporter in cardiac cells, but our results do not 


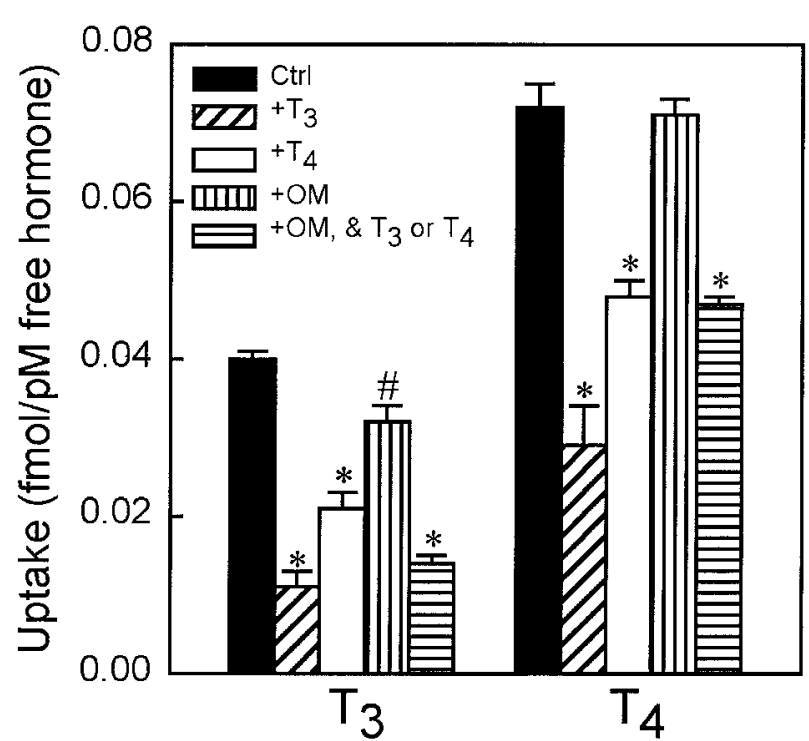

Figure 4 Effect of unlabeled $\mathrm{T}_{3}, \mathrm{~T}_{4}$, oligomycin (OM) and combinations of these compounds on the 30-min $\left[{ }^{125} I\right] \mathrm{T}_{3}$ and $\left[{ }^{125} I\right] \mathrm{T}_{4}$ uptake in myoblasts. Unlabeled $\mathrm{T}_{3}$ and $\mathrm{T}_{4}(10 \mu \mathrm{M})$ were only present during incubation, whereas $\mathrm{OM}(10 \mu \mathrm{M})$ was present during preincubation (30 $\mathrm{min})$ and incubation. The effect of the combination of $\mathrm{OM}$ with unlabeled hormone on $\mathrm{T}_{3}$ and $\mathrm{T}_{4}$ uptake was tested by incubations with $\mathrm{OM}$ and $\mathrm{T}_{3}$ or $\mathrm{OM}$ and $\mathrm{T}_{4}$ respectively. The difference between the solid and the hatched bars (absence (control; Ctrl) and presence of $10 \mu \mathrm{M}$ unlabeled hormone) represents the saturable part of $\left[{ }^{125} \mathrm{I}\right] \mathrm{T}_{3}$ and $\left[{ }^{125} \mathrm{I}\right] \mathrm{T}_{4}$ uptake. Data are presented as means \pm S.E.M. of $6-18$ observations from three experiments. ${ }^{*} P<0.001$ vs control; ${ }^{\#} P<0 \cdot 01$ vs control.

allow any conclusion about the affinity of the transporter for $\mathrm{T}_{3}$ and $\mathrm{T}_{4}$ to be drawn. Studies with cultured anterior pituitary cells also suggested a common carrier for uptake of $\mathrm{T}_{3}$ and $\mathrm{T}_{4}$ (Everts et al. 1994). This is different from the situation in the liver, where separate carriers are presumably involved in uptake of $\mathrm{T}_{3}$ and $\mathrm{T}_{4}$ (Krenning et al. 1981). These differences suggest that thyroid hormone uptake is regulated in a tissue-specific manner, which may significantly influence total thyroid hormone bioactivity (Everts et al. 1996a, Hennemann et al. 1998, 2001).

The H9c2(2-1) cell line is frequently used as a model for cardiac myocytes (Eckel 1996, Brostrom et al. 2000, Wayman et al. 2001). However, the ability of the cells to form multinucleated tubes is a skeletal muscle rather than a cardiac muscle characteristic (Kimes \& Brandt 1976, Hescheler et al. 1991). Nevertheless, the morphological characteristics and several elements of the electrical and hormonal signaling pathway are similar to those of embryonic and adult cardiomyocytes respectively (Hescheler et al. 1991). An active transport mechanism has also been described for the uptake of $\mathrm{T}_{3}$ in intact rat skeletal muscle (van Hardeveld \& Kassenaar 1978, Pontecorvi \& Robbins 1986) and in a skeletal muscle cell line (Pontecorvi et al.

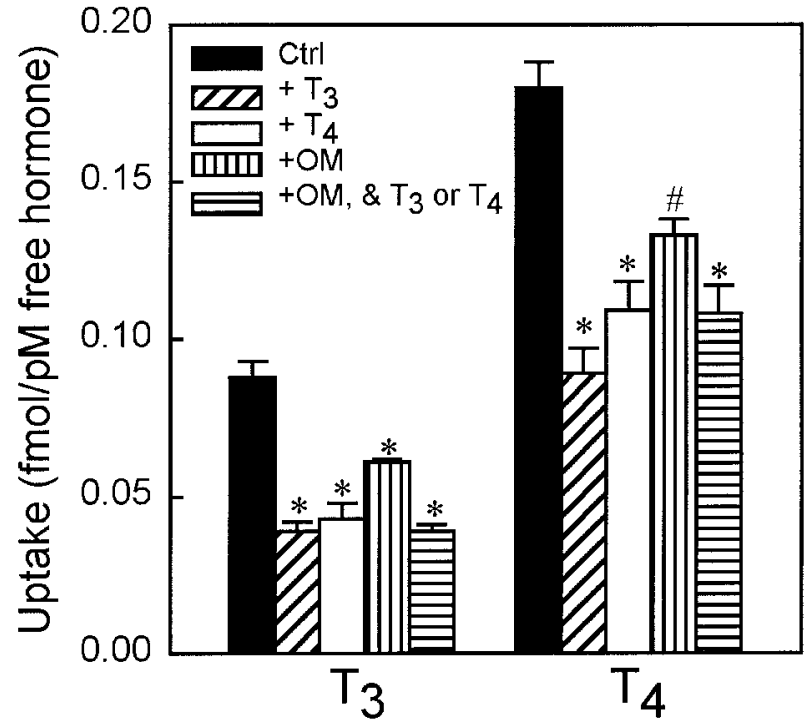

Figure 5 Effect of unlabeled $\mathrm{T}_{3}, \mathrm{~T}_{4}$, oligomycin $(\mathrm{OM})$ and combinations of these compounds on the 30-min [ $\left.{ }^{125} \mathrm{I}\right] \mathrm{T}_{3}$ and $\left[{ }^{125} \mathrm{I}\right] \mathrm{T}_{4}$ uptake in myotubes. Experiments were performed exactly as described for myoblasts (Fig. 4). The difference between the solid and the hatched bars (absence (control; Ctrl) and presence of $10 \mu \mathrm{M}$ unlabeled hormone) represents the saturable part of $\left[{ }^{125} \mathrm{I}\right] \mathrm{T}_{3}$ and $\left[{ }^{125} \mathrm{I}\right] \mathrm{T}_{4}$ uptake. Data are presented as means \pm S.E.M. of $6-18$ observations from three experiments. ${ }^{*} P<0 \cdot 001$ vs control; ${ }^{\#} P<0 \cdot 01$ vs control.

Table 1 Effects of Trp on 30-min uptake of [ $\left.{ }^{125} \mathrm{I}\right] \mathrm{T}_{3}$ and $\left[{ }^{125} \mathrm{I}\right] \mathrm{T}_{4}$ in myoblasts. H9c2(2-1) myoblasts were preincubated (30 $\mathrm{min})$ and incubated in the absence or presence of Trp. Data show the means \pm S.E.M. from two independent experiments

\begin{tabular}{|c|c|c|c|c|}
\hline & $\begin{array}{l}{\left[{ }^{125} \mathrm{I}_{\mathrm{T}} \text { uptake }\right.} \\
\left(\mathrm{fM} / \mathrm{pM} \text { free } \mathrm{T}_{3}\right)\end{array}$ & $\begin{array}{l}\text { Effect } \\
(\%)\end{array}$ & $\begin{array}{l}{\left[{ }^{125} \mathrm{IJT}_{4} \text { uptake }\right.} \\
\left(\mathrm{fM} / \mathrm{pM} \text { free } \mathrm{T}_{4}\right)\end{array}$ & $\begin{array}{l}\text { Effect } \\
(\%)\end{array}$ \\
\hline No additions & $0.035 \pm 0.001$ & & $0 \cdot 112 \pm 0 \cdot 003$ & \\
\hline $\operatorname{Trp}(0.5 \mathrm{mM})$ & $0.014 \pm 0.001^{*}$ & -60 & $0.077 \pm 0.003^{*}$ & -31 \\
\hline $\operatorname{Trp}(2 \mathrm{mM})$ & $0.011 \pm 0.001^{*}$ & -69 & $0.032 \pm 0.007^{*}$ & -71 \\
\hline
\end{tabular}

${ }^{*} P<0 \cdot 001$, Trp vs no additons.

1987); a mechanism that is dependent on the $\mathrm{Na}^{+}$gradient (Centanni \& Robbins 1987). In agreement with our study in cardiomyocytes where $\mathrm{Na}^{+}$dependency was also evaluated by substituting $\mathrm{Na}^{+}$with choline (van der Putten et al. 2001), $\mathrm{T}_{3}$ uptake in $\mathrm{H} 9 \mathrm{c} 2(2-1)$ cells was $\mathrm{Na}^{+}$ independent. Thus, based on $\mathrm{Na}^{+}$independency, the differentiated H9c2(2-1) cells exhibit a cardiac-like $\mathrm{T}_{3}$ transport mechanism.

Previously, we showed that $\operatorname{Trp}$ inhibited $\mathrm{T}_{3}$ uptake and suggested that amino acid transport system $\mathrm{T}$ may be an accessory transport system in the uptake of thyroid hormones in heart (Everts et al. 1996b, van der Putten et al. 2001). In H9c2(2-1) cells, Trp also inhibited the uptake of $\mathrm{T}_{3}$, supporting this idea. Moreover, the effect of $\operatorname{Trp}$ on $\mathrm{T}_{3}$ 


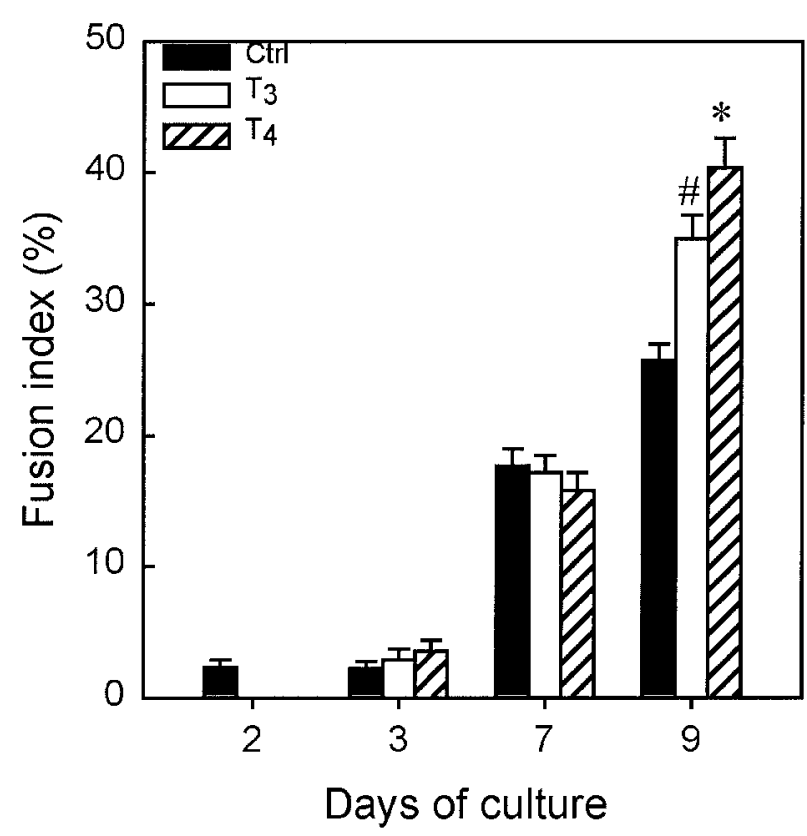

Figure 6 Effect of $T_{3}$ and $T_{4}$ on fusion index. Cells were cultured from day 2 to day 9 in DMEM supplemented with 1\% FCS and $5 \mathrm{nM} \mathrm{T}_{3}$ (open bars) or $50 \mathrm{nM} \mathrm{T}_{4}$ (hatched bars). Fusion index was determined at days 2, 3, 7 and 9 as described in Materials and Methods. Data are presented as means \pm S.E.M. of two independent experiments. ${ }^{\#} P<0.01$ and ${ }^{*} P<0.001, \mathrm{~T}_{3}$ or $\mathrm{T}_{4}$ vs control at day 9 .

uptake was comparable with the effect of unlabeled $\mathrm{T}_{3}$ : $69 \%$ and $73 \%$ in myoblasts, $49 \%$ and $60 \%$ in myotubes respectively. In general, incubations with excess unlabeled $\mathrm{T}_{3}$ distinguish membrane-associated $\mathrm{T}_{3}$ from that translocated across the plasma membrane by a specific mechanism (Cheng 1983, Pontecorvi \& Robbins 1986, van der Putten et al. 2001). Thus, it seems that Trp inhibits specific $\mathrm{T}_{3}$ uptake in $\mathrm{H} 9 \mathrm{c} 2(2-1)$ cells. Trp also inhibited the uptake of $\mathrm{T}_{4}$ to the same extent as that of $\mathrm{T}_{3}(71 \%$ and $69 \%$ respectively). When compared with the inhibition by unlabeled $\mathrm{T}_{4}(33 \%)$, the effect of $\operatorname{Trp}$ was higher $(71 \%)$, but comparable with the inhibitory effect of unlabeled $\mathrm{T}_{3}$ on $\mathrm{T}_{4}$ uptake $(60 \%)$. These findings further support the idea that $T_{4}$ and $T_{3}$ share a common mechanism, in which amino acid transport system $\mathrm{T}$ may play a role. Recently, a novel member of this system, called TAT1, has been identified (Kim et al. 2001). When expressed in Xenopus laevis oocytes, TAT1 did not induce uptake of $\mathrm{T}_{3}$ or $\mathrm{T}_{4}$ (Kim et al. 2001). In addition to TAT1, a number of transporters belonging to different families have been identified as potential thyroid hormone transporters (Hennemann et al. 2001). It is possible that some of these transporters are involved in thyroid hormone transport into the heart.

$\mathrm{T}_{3}$ and $\mathrm{T}_{4}$ significantly increased the fusion index at day 9 , indicating that the $T_{3}$ and $T_{4}$ uptake mechanisms are important for the availability of thyroid hormones during differentiation. This is further supported by the observation that thyroid hormone uptake, most evident that of $\mathrm{T}_{4}$, is higher in myotubes compared with myoblasts. Gonçalves et al. (1989) also reported a higher uptake in differentiated cells compared with undifferentiated cells. Although actions of $\mathrm{T}_{4}$ on differentiation have been described (Brik \& Shainberg 1990, Nakashima et al. $1998 a, 1998 b)$, it is generally thought that $T_{3}$ and not $T_{4}$ is the main regulator of such processes. The affinity of $\mathrm{T}_{4}$ for the nuclear $\mathrm{T}_{3}$ receptor is one-tenth that of $\mathrm{T}_{3}$ (Muñoz \& Bernal 1997). The effects on differentiation of the H9c2(2-1) cells were examined under conditions in which the free $T_{4}$ concentration was 7 -fold higher than that of $\mathrm{T}_{3}$, i.e. 1.5 and $0.2 \mathrm{nM}$ respectively. Thus, theoretically, $\mathrm{T}_{4}$ may have stimulated differentiation of the $\mathrm{H} 9 \mathrm{c} 2(2-1)$ cells by association with the nuclear $\mathrm{T}_{3}$ receptor. If $\mathrm{T}_{4}$ by itself does not induce differentiation, it should be deiodinated to $T_{3}$ to allow binding to the nuclear $\mathrm{T}_{3}$ receptor. We found a small DI activity in myoblasts and myotubes of the H9c2(2-1) cells that was around $1 \%$ of the activity in rat liver. This is consistent with the findings of Mori et al. (1991), who reported DI activity in neonatal rat cardiomyocytes. In a recent study by Sabatino et al. (2000), DI activity in rat and human heart was measured. The values were comparable, and amounted to around $1 \%$ of DI activity in rat liver. Although DI converts $T_{4}$ into $T_{3}$, it is thought to play a minor role in the local production of $\mathrm{T}_{3}$ (Visser 1996). Local $\mathrm{T}_{3}$ production is primarily mediated by DII (Visser 1996), but we could not detect DII activity in H9c2(2-1) myoblasts. Studies on the presence of DII have only been performed in the adult heart. DII mRNA was found in human, but not in rat heart (Croteau et al. 1996). While Naumann et al. (1994) could not detect DII activity in rat heart, Sabatino et al. (2000) found a low DII activity in human and rat heart. Finally, non-genomic effects of $T_{4}$ have been reported (Davis et al. 2002). $\mathrm{T}_{4}$ appears to activate signal transducing kinases (Davis et al. 2002), amongst them those involved in differentiation such as the mitogen-activating protein kinase pathway (Chun et al. 2000).

In summary, the H9c2(2-1) cell line provides a useful model system for examination of thyroid hormone uptake in cardiac cells. Uptake of $T_{3}$ and $T_{4}$ is regulated by a specific and energy-dependent mechanism, and it appears that $T_{3}$ and $T_{4}$ share a common transport mechanism in $\mathrm{H} 9 \mathrm{c} 2(2-1)$ cells. Furthermore, the ability of both $\mathrm{T}_{3}$ and $\mathrm{T}_{4}$ to induce differentiation suggests that the thyroid hormone uptake mechanisms are important for the availability of thyroid hormones during further development. Another potential application of our study is a therapeutic approach to target the heart with $\mathrm{T}_{3}, \mathrm{~T}_{4}$ or analogs (Klein \& Ojamaa 2001, Verhoeven et al. 2002), since a failing heart recapitulates the fetal profile of gene expression (Klein \& Ojamaa 2001, Sussman 2001). 


\section{Acknowledgements}

The authors thank TJ Visser and E C H Friesema (Department of Internal Medicine, Erasmus University Medical School, Rotterdam, The Netherlands) for constructive discussions. This work was supported by The Netherlands Heart Foundation (grant no. 96.175) and The Netherlands Organization for Scientific Research (grant no. 903.40.194).

\section{References}

Benvenga S \& Robbins J 1990 Enhancement of thyroxine entry into low density lipoprotein (LDL) receptor-competent fibroblasts by LDL: an additional mode of entry of thyroxine into cells. Endocrinology 126 933-941.

Brik H \& Shainberg A 1990 Thyroxine induces transition of red towards white muscle in cultured heart cells. Basic Research in Cardiology 85 237-246.

Brostrom MA, Reilly BA, Wilson FJ \& Brostrom CO 2000 Vasopressin-induced hypertrophy in $\mathrm{H} 9 \mathrm{c} 2$ heart-derived myocytes. International Journal of Biochemistry and Cell Biology 32 993-1006.

Burrow GN, Fisher DA \& Larsen PR 1994 Maternal and fetal thyroid function. New England Journal of Medicine 331 1072-1078.

Canavan JP, Holt J \& Goldspink DF 1994 The influence of thyroid hormones on the growth of the atria and ventricles of the heart in immature rats. Journal of Endocrinology 142 171-179.

Centanni M \& Robbins J 1987 Role of sodium in thyroid hormone uptake by rat skeletal muscle. Journal of Clinical Investigation $\mathbf{8 0}$ 1068-1072.

Cheng SY 1983 Characterization of binding and uptake of $3,3^{\prime}, 5$-L-triiodothyronine in cultured mouse fibroblasts. Endocrinology $1121754-1762$.

Chun YK, Kim J, Kwon S, Choi SH, Hong F, Moon K, Kim JM, Choi SL, Kim BS, Ha J \& Kim SS 2000 Phosphatidylinositol 3-kinase stimulates muscle differentiation by activating p38 mitogen-activated protein kinase. Biochemical and Biophysical Research Communications 276 502-507.

Cluzeaut F \& Maurer-Schultze B 1986 Proliferation of cardiomyocytes and interstitial cells in the cardiac muscle of the mouse during preand postnatal development. Cell and Tissue Kinetics 19 267-274.

Croteau W, Davey JC, Galton VA \& Germain DLS 1996 Cloning of the mammalian type II iodothyronine deiodinase. A selenoprotein differentially expressed and regulated in human and rat brain and other tissues. Journal of Clinical Investigation 98 405-417.

Davis PJ, Tillmann HC, Davis FB \& Wehling M 2002 Comparison of the mechanisms of nongenomic actions of thyroid hormone and steroid hormones. Journal of Endocrinological Investigation 25 377-388.

Docter R, Krenning EP, Bernard HF \& Hennemann G 1987 Active transport of iodothyronines into human cultured fibroblasts. Journal of Clinical Endocrinology and Metabolism 65 104-107.

Downs TR \& Wilfinger WW 1983 Fluorometric quantification of DNA in cells and tissues. Analytical Biochemistry 131 538-547.

Eckel J 1996 Direct effects of glimepiride on protein expression of cardiac glucose transporters. Hormone and Metabolic Research $\mathbf{2 8}$ 508-511.

Everts ME, Docter R, Moerings EPCM, van Koetsveld PM, Visser TJ, de Jong M, Krenning EP \& Hennemann Gi 1994 Uptake of thyroxine in cultured anterior pituitary cells of euthyroid rats. Endocrinology 134 2490-2497.

Everts ME, de Jong M, Lim C, Docter R, Krenning EP, Visser TJ \& Hennemann G 1996a Different regulation of thyroid hormone transport in liver and pituitary: its possible role in the maintenance of low $\mathrm{T}_{3}$ production during nonthyroidal illness and fasting in man. Thyroid 6 357-366.
Everts ME, Verhoeven FA, Bezstarosti K, Moerings EPCM, Hennemann G, Visser TJ \& Lamers JMJ 19966 Uptake of thyroid hormones in neonatal rat cardiac myocytes. Endocrinology 137 4235-4242.

Gerrelli D, Huntriss JD \& Latchman DS 1994 Antagonistic effects of retinoic acid and thyroid hormone on the expression of the tissue-specific splicing protein $\mathrm{SmN}$ in a clonal cell line derived from rat heart. Journal of Molecular and Cellular Cardiology 26 713-719.

Gonçalves E, Lakshmanan M \& Robbins J 1989 Triiodothyronine transport into differentiated and undifferentiated mouse neuroblastoma cells (NB41A3). Endocrinology 124 293-300.

van Hardeveld C \& Kassenaar AAH 1978 Thyroid hormone uptake and $\mathrm{T}_{4}$ derived $\mathrm{T}_{3}$ formation in different skeletal muscle types of normal and hypothyroid rats. Acta Endocrinologica 88 306-320.

Hennemann G, Everts ME, de Jong M, Lim C, Krenning EP \& Docter R 1998 The significance of plasma membrane transport in the bioavailability of thyroid hormone. Clinical Endocrinology 48 1-8.

Hennemann G, Docter R, Friesema ECH, de Jong M, Krenning EP \& Visser TJ 2001 Plasma membrane transport of thyroid hormones and its role in thyroid hormone metabolism and bioavailability. Endocrine Reviews 22 451-476.

Hescheler J, Meyer R, Plant S, Krautwurst D, Rosenthal W \& Schultz G 1991 Morphological, biochemical, and electrophysiological characterization of a clonal cell $(\mathrm{H} 9 \mathrm{c} 2)$ line from rat heart. Circulation Research 69 1476-1486.

Huang CJ, Geller HM, Green WL \& Craelius W 1999 Acute effects of thyroid hormone analogs on sodium currents in neonatal rat myocytes. Journal of Molecular and Cellular Cardiology 31 881-893.

Kim DK, Kanai Y, Chairoungdhua A, Matsuo H, Cha SH \& Endou H 2001 Expression cloning of a $\mathrm{Na}^{+}$-independent aromatic amino acid transporter with structural similarity to $\mathrm{H}^{+} /$monocarboxylate transporters. Journal of Biological Chemistry 276 17221-17228.

Kimes BW \& Brandt L 1976 Properties of a clonal muscle cell line from rat heart. Experimental Cell Research 98 367-381.

Klein I \& Ojamaa K 2001 Thyroid hormone - targeting the heart. Endocrinology 142 11-12.

Kragie L 1994 Membrane iodothyronine transporters. Part I: Review of physiology. Endocrine Research 40 319-341.

Krenning EP, Docter R, Bernard B, Visser TJ \& Hennemann G 1981 Characteristics of active transport of thyroid hormone into rat hepatocytes. Biochimica et Biophysica Acta 676 314-320.

Lakshmanan M, Gonçalves E, Lessly G, Foti D \& Robbins J 1990 The transport of thyroxine into mouse neuroblastoma cells, NB41A3: the effect of L-system amino acids. Endocrinology 126 3245-3250.

Lazar MA 1993 Thyroid hormone receptors: multiple forms, multiple possibilities. Endocrine Reviews 14 184-193.

Lowry OH, Rosebrough NJ, Farr AL \& Randall RJ 1951 Protein measurement with the Folin phenol reagent. Journal of Biological Chemistry 193 265-275.

Mayhew TM, Pharaoh A, Austin A \& Fagan DG 1997 Stereological estimates of nuclear number in human ventricular cardiomyocytes before and after birth obtained using physical disectors. Journal of Anatomy 191 107-115.

Mol JA \& Visser TJ 1985 Synthesis and some properties of sulfate esters and sulfamates of iodothyronines. Endocrinology 117 1-7.

Mori Y, Nishikawa M, Toyoda N, Yonemoto T, Matsubara H \& Inada M 1991 Iodothyronine $5^{\prime}$-deiodinase activity in cultured rat myocardial cells: characteristics and effects of triiodothyronine and angiotensin II. Endocrinology 128 3105-3112.

Muñoz A \& Bernal J 1997 Biological activities of thyroid hormone receptors. European Journal of Endocrinology 137 433-445.

Nakashima K, Ohtsuka A \& Hayashi K 1998a Comparison of the effects of thyroxine and triiodothyronine on protein turnover and apoptosis in primary chick muscle cell cultures. Biochemical and Biophysical Research Communications 251 442-448. 
Nakashima K, Ohtsuka A \& Hayashi K 1998 b Effects of thyroid hormones on myofibrillar proteolysis and activities of calpain, proteasome, and cathepsin in primary cultured chick muscle cells. Journal of Nutritional Science and Vitaminology 44 799-807.

Nauman A, Nauman J, Porta S \& Grzesniuk W 1994 Iodothyronine $-5^{\prime}$-deiodinase in rat heart, regulatory action of catecholamines. In Heart and Thyroid, pp 172-196. Eds LE Braverman, O Eber \& W Langsteger. Cambridge, MA: Blackwell Scientific Publications Inc.

Obrégon MJ, Calvo RM, Escobar del Rey F \& Morreale de Escobar G 1998 Thyroid hormones and fetal development. In The Thyroid and Age, pp 49-73. Eds A Pinchera, K Mann \& U Hostalek. Stuttgart: Schattauer.

Pinson 1990 Neonatal rat heart muscle cells. In Cell Culture Techniques in Heart and Vessel Research, pp 20-35. Ed. HM Piper. Berlin: Springer.

Pontecorvi A \& Robbins J 1986 Energy-dependent uptake of 3,5,3'-triiodo-L-thyronine in rat skeletal muscle. Endocrinology 119 $2755-2761$.

Pontecorvi A, Lakshmanan M \& Robbins J 1987 Intracellular transport of 3,5,3'-triiodo-L-thyronine in rat skeletal myoblasts. Endocrinology $1212145-2152$.

van der Putten HHAGM, Joosten BJLJ, Klaren PHM \& Everts ME 2001 Characterization of uptake and compartmentalization of 3,5,3'-triiodothyronine in cultured neonatal rat cardiomyocytes. Journal of Endocrinology 171 183-192.

Rosic MA, Pantovic SB, Lucic AP, Ribarac-Stepic N \& Andjelkovic I 2001 Kinetics of thyroxine $\left(T_{4}\right)$ and triiodothyronine $\left(T_{3}\right)$ transport in the isolated rat heart. Experimental Physiology 86 13-18.
Sabatino L, Iervasi G, Ferrazzi P, Francesconi D \& Chopra IJ 2000 A study of iodothyronine $5^{\prime}$-monodeiodinase activities in normal and pathological tissues in man and their comparison with activities in rat tissues. Life Sciences 68 191-202.

Sterling K \& Brenner MA 1966 Free thyroxine in human serum: simplified measurement with the aid of magnesium precipitation. Journal of Clinical Investigation 45 153-163.

Sussman MA 2001 When the thyroid speaks, the heart listens. Circulation Research 89 557-559.

Verhoeven FA, Moerings EPCM, Lamers JMJ, Hennemann G, Visser TJ \& Everts ME 2001 Inhibitory effects of calcium blockers on thyroid hormone uptake in neonatal rat cardiac myocytes. American Journal of Physiology 21 H1985-H1991.

Verhoeven FA, van der Putten HHAGM, Hennemann G, Lamers JMJ, Visser TJ \& Everts ME 2002 Uptake of triiodothyronine and triiodothyroacetic acid in neonatal rat cardiomyocytes: effect of metabolites and analogs. Journal of Endocrinology 173 247-255.

Visser TJ 1996 Pathways of thyroid hormone metabolism. Acta Medica Austriaca 23 10-16.

Wayman N, McDonald MC, Thompson AS, Threadgill MD \& Thiemermann C 2001 5-Aminoisoquinelinone, a potent inhibitor of poly (adenosine $5^{\prime}$-diphosphate ribose) polymerase, reduces myocardial infarct size. European Journal of Pharmacology $\mathbf{4 3 0}$ 93-100.

Received in final form 20 August 2002

Accepted 21 August 2002 